Journal of Clinical Investigation

Vol. 41, No. 5, 1962

\title{
ERYTHROID CELL MATURATION AND HEMOGLOBIN SYNTHESIS IN MEGALOBLASTIC ANEMIA*
}

\author{
By DAVID G. NATHAN AND FRANK H. GARDNER with THE TECHNICAL ASSISTANCE OF \\ VIRGINIA B. LEMIRE
}

\author{
(From the Richard C. Curtis Hematology Laboratory, Peter Bent Brigham Hospital, and the \\ Department of Medicine, Harvard Medical School, Boston, Mass.)
}

(Submitted for publication August 8, 1961 ; accepted December 28, 1961)

Recent observations of the rate of glycine uptake into heme and globin during normal red cell maturation in man have led to the conclusion that heme and globin may be synthesized independently during the development of the mature erythrocyte (1). Globin appears to be maximally synthesized at a primitive stage of erythrocyte development with a nearly linear decline of synthetic rate as the cell matures, whereas heme is maximally synthesized midway in maturation with less activity both early and late in red cell development.

With such data available, it was of interest to evaluate heme and globin synthesis in megaloblastic anemias in an attempt to define not only relative rates of heme and globin synthesis, but also to examine the erythrocyte maturation time and the in vivo insertion of iron into protoporphyrin in such disorders.

The data reported in this paper represent the experience of this laboratory in studies of four patients with pernicious anemia of varying severity. These results and their interpretation are compared with similar data, derived from the study of normal patients, which have been previously reported (1).

\section{MATERIALS AND METHODS}

Subjects. The laboratory data supporting the diagnosis of pernicious anemia in the four patients are presented in Table I. All four patients received diets and fluids as desired throughout the studies. Transfusion therapy of $400 \mathrm{ml}$ of packed red cells was given to $\mathrm{Pa}-$ tient 3 during the two days preceding the study. $\mathrm{Pa}-$ tient 2 received $1,000 \mu \mathrm{g}$ of vitamin $B_{12}$ subcutaneously 1 hour before radioactive isotopes were administered. The patients received $1.5 \mathrm{~g}$ sodium benzoate by mouth each day for assay of urinary hippuric acid specific activity.

* Supported by United States Public Health Service Grant A-956 (C4-5-6), The Medical Foundation, Inc., The Milton Fund, The Permanent Charity Fund, and the John A. Hartford Foundation.
Methods. The method is based upon the assumption that a single intravenous dose of glycine-2- $\mathrm{C}^{14}$ briefly labels the newly synthesized heme and globin of all of the erythroid cell precursors of the marrow. These cells emerge from the marrow as newly formed erythrocytes bearing heme and globin specific activities that are proportional to their uptake of the radioactive precursor and their previous or subsequent synthesis of heme and globin from nonradioactive glycine. The daily increment of $\mathrm{C}^{14}$ specific activity in the heme and globin of peripheral blood, therefore, reflects not only the relative number of cells of various stages of maturation which were present in the marrow at the time of the injection of the labeled precursor, but also the relative rates of heme and globin synthesis within the cells. The incremental curves are, in effect, "mirror images" of the erythroid marrow occurrences, since the cells that emerged on the first day after day zero (the day of isotope administration) were among the most mature marrow cells on day zero. The cells that emerged on the following days were progressively immature on day zero. Small daily gains in specific activity after the major daily increments of the $\mathrm{C}^{14}$ represent the release of cells that were not present in the marrow at the time of the intravenous injection, but which were exposed to a relatively low concentration of glycine-2- $\mathrm{C}^{14}$ that persisted in the marrow for a long time (2). The radioactive iron also labels the marrow erythroid cells and hence the peripheral erythrocytes. The rate of $\mathrm{Fe}^{50}$ incorporation into marrow erythroid cells and heme may, however, be significantly slower than that of glycine-2-C $\mathrm{C}^{14}(3,4)$.

Each subject received a single intravenous dose of $100 \mu \mathrm{c}$ of glycine-2-C $\mathrm{C}^{14}$ and nearly simultaneously $10 \mu \mathrm{c}$ of $\mathrm{Fe}^{\mathrm{s} \theta}$ as ferrous citrate bound to autologous or group $\mathrm{AB}$ $\mathrm{Rh}$ positive plasma. Subjects 1 and 4 received $100 \mu \mathrm{c}$ $\mathrm{Cr}^{51}$ as $\mathrm{NaCr}^{51} \mathrm{O}_{4}$-labeled autologous red cells for measurement of red cell survival. Blood samples of $10 \mathrm{ml}$ were drawn daily for 10 days. In each sample the cumulative and incremental $\mathrm{C}^{14}$ millimolar specific activity of hemin glycine and globin glycine was determined together with the per cent uptake of $\mathrm{Fe}^{50}$ by red cells and, if present, the specific activity of whole blood for $\mathrm{Cr}^{51}$. In two cases cumulative $\mathrm{Fe}^{59}$ hemin specific activity was also measured. The methods and calculations were those previously described (1). $\mathrm{Fe}^{59}$ hemin specific activity and the $\mathrm{Cr}^{51}$ whole blood radioactivity were determined by well-type crystal scintillation spectrometry of the iso- 
TABLE I

Hematologic studies in four patients with pernicious anemia

\begin{tabular}{|c|c|c|c|c|}
\hline & \multicolumn{4}{|c|}{ Patients } \\
\hline & 1 & 2 & 3 & 4 \\
\hline Hematocrit & 25 & 20 & 39 & 19.5 \\
\hline White blood cells & 4,000 & 12,500 & 6,500 & 7,200 \\
\hline Platelets & 45,000 & 175,000 & Not done & 217,000 \\
\hline Reticulocytes, \% & 1.5 & 0.2 & 0.8 & 1.8 \\
\hline Serum iron & 122 & 124 & 184 & 173 \\
\hline Gastric acid & None & None (Diagnex) & None & None \\
\hline $\mathrm{Co}^{60}$-vitamin $\mathrm{B}_{12}$ absorption, $\%$ & $\mathbf{0}$ & 3.5 & 3 & $\mathbf{0}$ \\
\hline Morphology, peripheral blood & $\begin{array}{l}\text { Macrocytosis, poikilo- } \\
\text { cytosis, few hyperseg- } \\
\text { mented polys }\end{array}$ & $\begin{array}{l}\text { Macrocytosis, poikilo- } \\
\text { cytosis, many hyper- } \\
\text { segmented polys }\end{array}$ & $\begin{array}{l}\text { Macrocytosis; hyper- } \\
\text { segmented polys } \\
\text { observed }\end{array}$ & $\begin{array}{l}\text { Macrocytosis, poikilo- } \\
\text { cytosis, hyperseg- } \\
\text { mented polys }\end{array}$ \\
\hline $\begin{array}{l}\text { Morphology, erythroid bone } \\
\text { marrow }\end{array}$ & $\begin{array}{l}\text { Highly erythroid; ap- } \\
\text { prox. } 50 \% \text { of ery- } \\
\text { throid cells were } \\
\text { primitive megalo- } \\
\text { blasts; remainder } \\
\text { showed megaloblastic } \\
\text { changes }\end{array}$ & $\begin{array}{l}\text { Highly erythroid; al- } \\
\text { most all erythroid } \\
\text { cells were primitive } \\
\text { megaloblasts; a few } \\
\text { megaloblastic matur- } \\
\text { ing cells seen }\end{array}$ & $\begin{array}{l}\text { Normal } \mathrm{M}: \mathrm{E} \text { ratio; } \\
\text { approx. } 15 \% \text { of ery- } \\
\text { throid cells were } \\
\text { primitive megalo- } \\
\text { blasts; many normo- } \\
\text { blastic cells seen }\end{array}$ & $\begin{array}{l}\text { Highly erythroid; ap- } \\
\text { prox. } 25 \% \text { of ery- } \\
\text { throid cells were } \\
\text { primitive megalo- } \\
\text { blasts; all erythroid } \\
\text { cells were megalo- } \\
\text { blastic }\end{array}$ \\
\hline Reticulocyte peak, \% & 3.5 & 18.6 & None observed & 8 \\
\hline Time of reticulocyte peak, days & 10 & 5 & None observed & 6 \\
\hline Maximum hematocrit & 44 & 44 & 43 & 42 \\
\hline
\end{tabular}

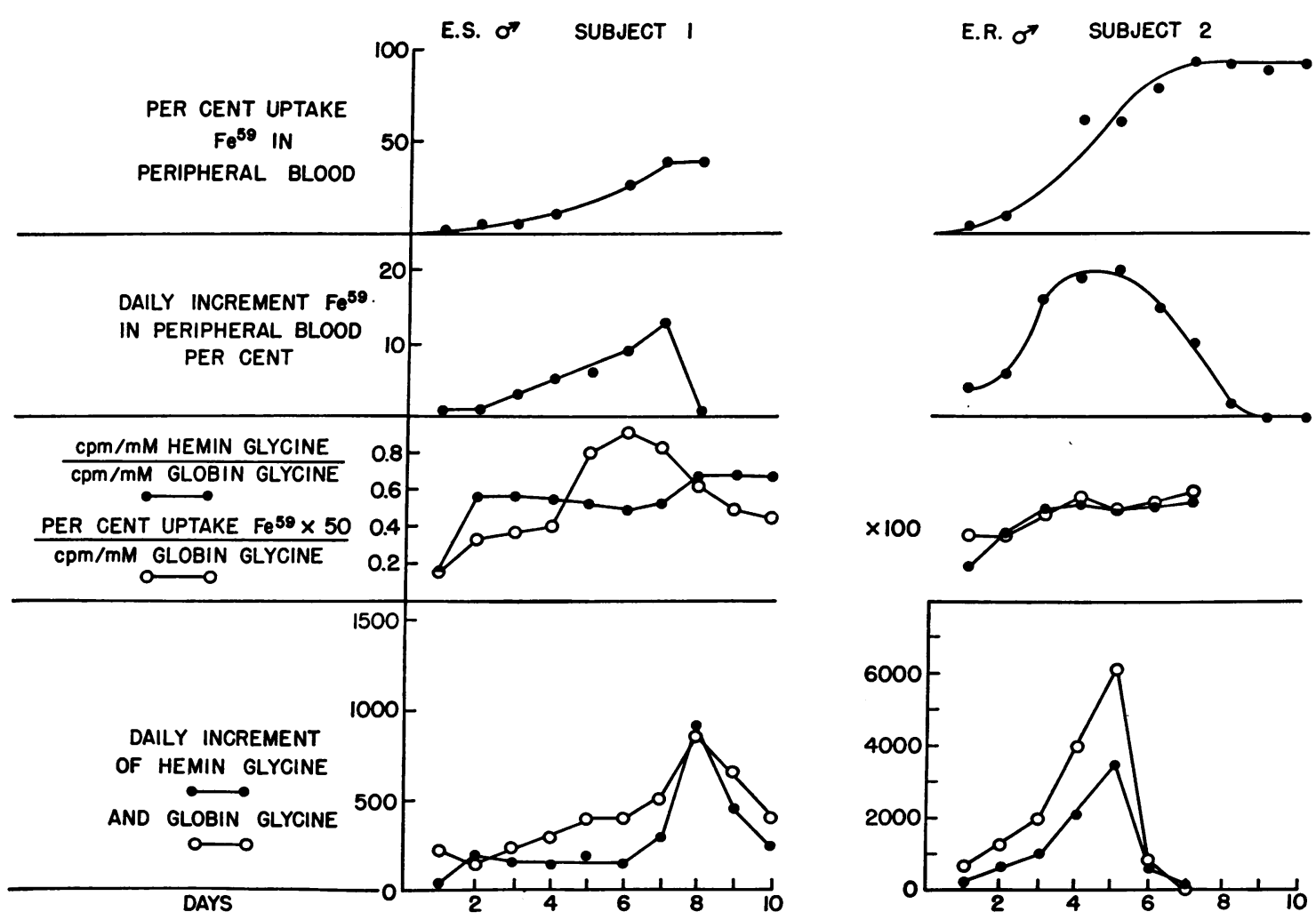

Fig. 1. Isotopic data derived from studies of Subjects 1 and 2. The data are presented in four vertical sections for each subject, numbered from the top down. Each section is identified on the ordinate. In section three the per cent uptake of $\mathrm{Fe}^{50}$ by peripheral blood is multiplied by a constant for the purposes of convenient charting. 
lated hemin and whole blood. The 95 per cent confidence limits of the $\mathrm{C}^{14}$ and $\mathrm{Fe}^{59}$ count rates were no greater than 5 per cent of the net count rates for $\mathrm{Fe}^{69}$ and 2 to 3 per cent for $\mathrm{C}^{14}$ and $\mathrm{Cr}^{51}$.

\section{RESULTS}

The data for each subject are presented in Figures 1 and 2. Similar data for a normal individual are presented in Figure 3 for convenient comparison.

Figure 1, Subject 1. This patient presented marked megaloblastic alterations in the bone marrow. The majority of the erythroid cells were primitive megaloblasts, although evidence of megaloblastic maturation was present. The red cell $\mathrm{Fe}^{59}$ uptake was abnormally delayed (section one, top) and the peak increment of $\mathrm{Fe}^{59}$ in peripheral cells was on day 7 (section two). Section three revealed that the maximal increment of $\mathrm{Fe}^{59}$ appeared in the peripheral red cells before the maximal increment of $\mathrm{C}^{\mathbf{1 4}}$-labeled hemin, which indicated a detectable hiatus between protoporphyrin synthesis from glycine and iron insertion into protoporphyrin. Marked delay of the maximal $\mathrm{C}^{14}$ appearance in both heme and globin was observed in section four. Not only is an apparent maturation delay observed, but the glycine uptake into both heme and globin appears to be synchronous, as opposed to the findings in normal subjects (Figure 3).

Figure 1, Subject 2. This patient presented a bone marrow comprised almost entirely of primitive megaloblasts. Only a small population of maturing megaloblasts was observed. This circumstance afforded an opportunity to study nearly a single population of erythroid precursors. Accordingly, the patient received $1,000 \mu \mathrm{g}$ vitamin $B_{12}$ subcutaneously 1 hour before the intravenous administration of the radioactive isotopes. Section one reveals that after a short delay of 2 days there was prompt appearance of injected radioiron in circulating red cells. The $\mathrm{Fe}^{59}$ incremental curve is bell-shaped with somewhat similar increments of $\mathrm{Fe}^{59}$ red cell radioactivity between days 3 and 6 (section two). No significant hiatus between $\mathrm{Fe}^{59}$
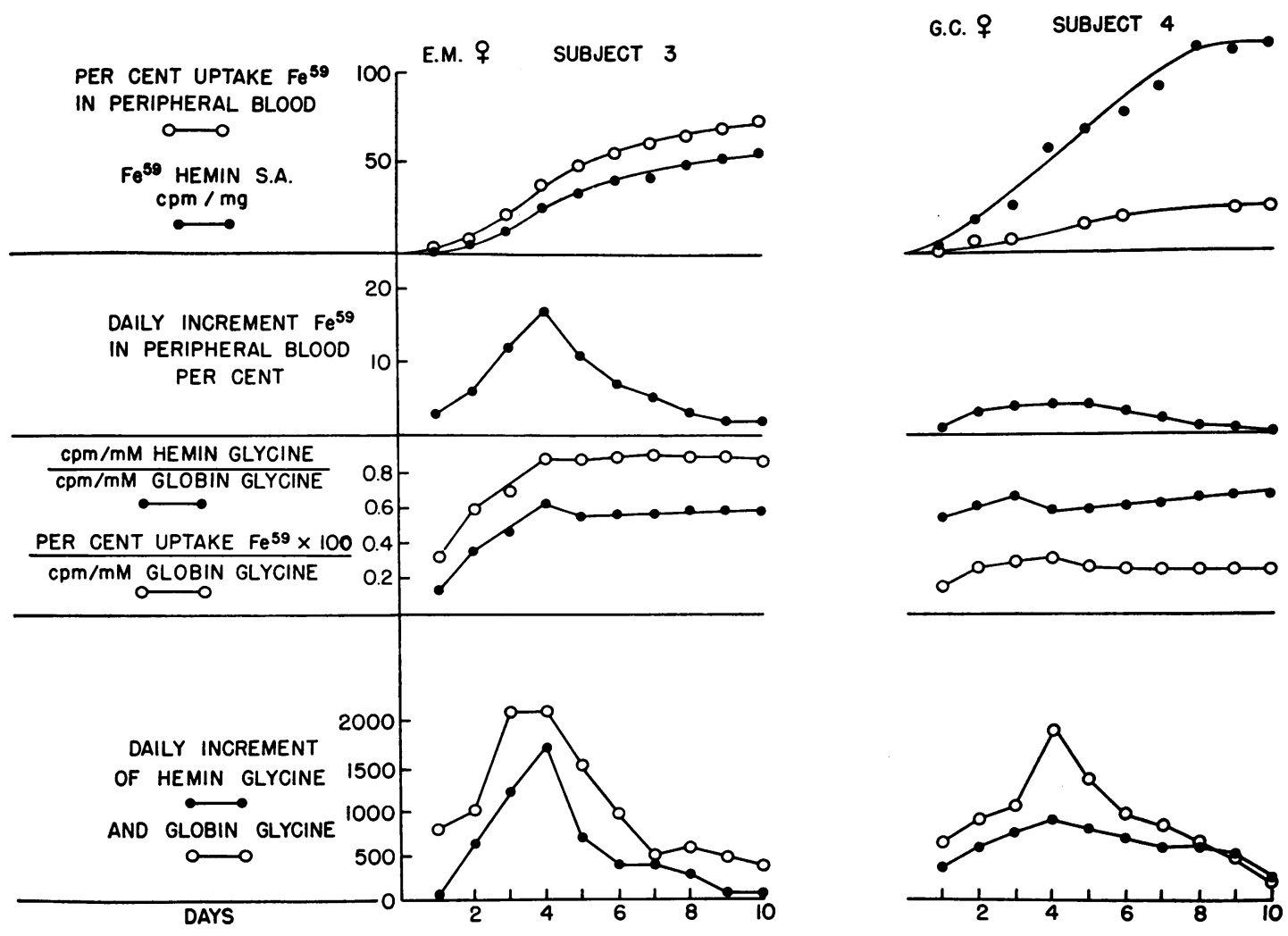

Fig. 2. Isotopic data derived from studies of Subjects 3 and 4. 
red cell radioactivity and $\mathrm{C}^{14}$ hemin specific activity is observed in section three.

The incremental curve of $\mathrm{C}^{14}$-labeled hemin and globin glycine is a striking departure from normal. Small increments were observed in both for the first 3 days. The bulk of the circulating radioactivity in the two compounds emerged in the fourth and particularly on the fifth day, coincident with the peripheral reticulocyte peak. This homogeneous population of cells that emerged on days 4 and 5 may well have been converted to pronormoblasts by the administered vitamin $\mathrm{B}_{12}$. They then matured to a stage commensurate with their release from the marrow in 4 or 5 days (depending upon their stage of megaloblastic development at the time of vitamin $\mathrm{B}_{12}$ administration) and emerged from the marrow nearly as a single cohort bearing the familiar relationship of pronormoblastic globin glycine to hemin glycine-viz, a higher specific activity of globin glycine.

Figure 2, Subject 3. This patient had a normal hematocrit. Although obvious megaloblastic alterations were noted in the granulocyte precursors and megakaryocytes of her bone marrow, the erythoid cells were only moderately abnormal. Many normoblastic erythroid precursors were observed. Approximately 15 per cent of the erythroid cells were primitive megaloblasts.

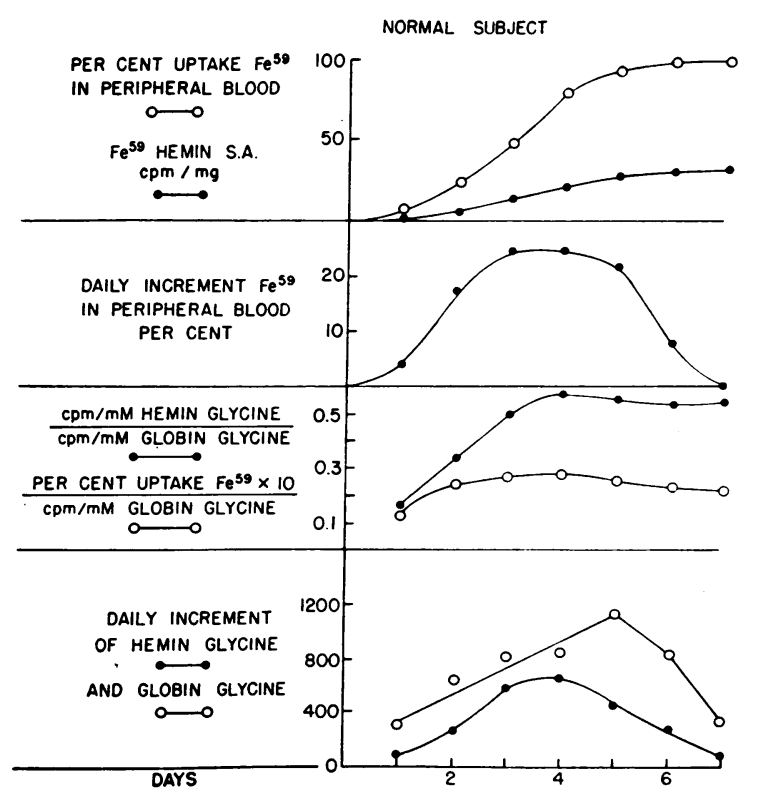

Fig. 3. ISOTOPIC DATA DERIVED FROM STUDY OF A NORMAL INDIVIDUAL.
Section one shows a somewhat slow appearance of $\mathrm{Fe}^{59}$ in both circulating red cells and hemin. The $\mathrm{Fe}^{59}$ hemin and red cell curves had nearly similar shapes, indicating only slightly detectable delay between red cell iron uptake and iron utilization for heme synthesis. Section two shows that the peak increment of $\mathrm{Fe}^{59}$ uptake was at day 4 . After this, a progressive but prolonged decrease in the rate of discharge of radioiron from the marrow was observed, as the labeled iron was slowly mobilized from marrow iron pools. Section three shows a minimal difference between $\mathrm{Fe}^{59}$ hemin and $\mathrm{C}^{14}$ hemin appearance. The curve of the $\mathrm{C}^{14}$ hemin glycine: $\mathrm{C}^{14}$ globin glycine ratio slowly rose after the seventh day. This was not observed in the $\mathrm{Fe}^{59}$ hemin: $\mathrm{C}^{14}$ globin glycine ratio curve. This difference is more clearly established by comparison of sections four and two. In section four it may be noted that $\mathrm{C}^{14}$ hemin and globin glycine specific activities emerged nearly simultaneously from days 1 to 6, during which time the majority of the label appeared. From days 7 to 10 a small secondary rise in both curves was noted, which was not observed in section two. Thus it appears that the small population of primitive megaloblasts which was present in this marrow required approximately 8 to 9 days to mature enough to emerge, but that this population of cells did not emerge bearing enough $\mathrm{Fe}^{59}$ to cause a secondary rise in the red cell $\mathrm{Fe}^{59}$ curve.

Figure 2, Subject 4. This subject's erythroid marrow was definitely megaloblastic, with approximately 20 per cent primitive megaloblasts present. Megaloblastic maturation was evident. No normoblastic erythroid cells were seen. The patient was transfused with $400 \mathrm{ml}$ of packed red cells 2 days before administration of the radioactive precursors. A bone marrow smear was not made after transfusion therapy $(5,6)$. Sections one and two portray the slow accumulation of $\mathrm{Fe}^{59}$-labeled hemin and red cells. If both curves of section one are adjusted to 100 per cent at their plateaus, they are seen to be nearly similar in shape. Section three again reveals a small difference between the emergence of $\mathrm{Fe}^{59}$ and $\mathrm{C}^{14}$ in hemin. The $\mathrm{C}^{\mathbf{1 4}}$ curve rises slightly after day 7 , whereas the $\mathrm{Fe}^{59}$ curve does not. The data of section four are very similar to those of Subject 3 . The bulk of the $\mathrm{C}^{14}$ hemin and globin. appeared synchronously by day 6 , but after the seventh day 
secondary elevations of the $\mathrm{C}^{14}$ hemin and $\mathrm{C}^{14}$ globin glycine curves were observed. No such alteration in the $\mathrm{Fe}^{59}$ red cell curve was noted.

\section{DISCUSSION}

After administration of glycine-2- $\mathrm{C}^{14}$ and $\mathrm{Fe}^{59}$ citrate to normal individuals (1), daily increments in specific activity of $\mathrm{Fe}^{59}$ red cell and hemin and $\mathrm{C}^{14}$ hemin glycine of peripheral blood are similar. ${ }^{1}$ The maximal daily increments are found 3 or 4 days after isotope administration, and the incremental curve is rather bell-shaped. $\mathrm{C}^{14}$ globinglycine specific activity curves differ from the $\mathrm{Fe}^{59}$ and $\mathrm{C}^{14}$ hemin curves in normal subjects. There is nearly a linear increase in the daily increment to a maximal increment on day 5 after isotope administration. The rate of increase then rapidly falls. These data are interpreted to indicate that: 1) the maturation time of the normoblast is approximately 5 days; 2 ) maximal globin synthesis precedes maximal hemin synthesis during the maturation of normoblasts ; 3 ) the rates of glycine and iron incorporation into peripheral blood heme are not significantly different in vivo. Similar data derived from the four patients with megaloblastic anemia described in this report differ from normal individuals in several respects.

1. In the three untreated cases evidence for a population of erythroid cells with a prolonged maturation time is presented. In Patient 1 the major increments of $\mathrm{Fe}^{59}$-labeled red cells and of $\mathrm{C}^{14}$-labeled heme and globin glycine appear on days 7 and 8, respectively. In Patients 3 and 4 the bulk of the labeled cells appear by the fifth day, but a small cohort of cells appears between days 7 and 9, bearing discrete $\mathrm{C}^{\mathbf{1 4}}$ hemin and globin glycine labels. The $\mathrm{Fe}^{59}$ incremental curves are not similarly affected in Patients 3 and 4 (vide infra). These results are of importance in that they roughly correspond with the relative number of primitive megaloblasts observed in the erythroid marrow of the three patients (Table I) and indicate that the primitive megaloblast may mature to

\footnotetext{
${ }^{1} \mathrm{Fe}^{50}$ hemin curves are more nearly similar to $\mathrm{C}^{14}$ hemin curves than are $\mathrm{Fe}^{50}$ red cell curves. This is due to the fact that ordinarily much of the $\mathrm{Fe}^{59}$ which emerges 1 or 2 days after isotope administration is present as nonheme iron. ${ }^{\circ} \mathrm{Fe}^{\mathrm{s \theta}}$ hemin curves rise, therefore, more slowly than do $\mathrm{Fe}^{60}$ red cell curves during the first 2 days.
}

the point of emergence from the marrow at a rate much slower than normal. The maturation delay may be mainly in the early phases of cell development when cell division plays a prominent role in over-all maturation. After a certain more advanced stage is achieved, maturation and division times may proceed normally. This conclusion is supported by the in vitro findings of Reisner (7) and Astaldi (8) but is at variance with the conclusions drawn from $\mathrm{Fe}^{59}$ data in vivo by Finch and co-workers (9), Wallerstein and Pollycove (10), and Pollycove and Mortimer (3).

2. Although the delayed emergence of primitive cells is demonstrable with the $\mathrm{C}^{14}$ label in the three untreated cases, a delayed $\mathrm{Fe}^{59}$ peak increment is observed only in Patient 1. The $\mathrm{Fe}^{59}$ may well fail to label irreversibly the primitive megaloblasts in high enough concentration to produce a secondary rise in the $\mathrm{Fe}^{59}$ incremental curve. Although megaloblasts are labeled by $\mathrm{Fe}^{59}$ in vitro (11) not all such cells may be labeled, as noted in observations of pronormoblasts in vitro (12). In addition, the label may be eluted from the cells, as noted in reticulocytes by Pollycove and Mortimer (3). Thus, conclusions regarding the minimal megaloblastic maturation time drawn from $\mathrm{Fe}^{59}$ data alone may be misleading. In this sense the $\mathrm{Fe}^{59}$ and $\mathrm{C}^{14}$ heme curves differ from the normal in that they are not similar. The peak increment of $\mathrm{Fe}^{59}$ emerges 1 day prior to the peak increment of $\mathrm{C}^{14}$ hemin in Patient 1 , and the secondary $\mathrm{C}^{14}$ hemin peaks of Patients 3 and 4 are not observed with $\mathrm{Fe}^{59}$.

3. In all of the patients the $\mathrm{C}^{14}$ hemin glycine and globin glycine incremental curves are synchronous throughout the maturation period. No population of cells with increasing globin synthesis and decreasing heme synthesis, such as is noted in the primitive erythroid cells of normal subjects (cells that appear in the peripheral blood 5 days after glycine administration), emerges in the megaloblastic anemic patient. A speculative reason for this finding may be a decrease in the rate of globin synthesis in the primitive megaloblastic erythroid cell. Although vitamin $\mathrm{B}_{12}$ may play a primary role in protein synthesis, as noted by Wagle, Mehta and Johnson (13), other workers have not confirmed this impression $(14,15)$. No evidence of a gross defect in protoporphyrin synthesis was noted in these studies, in agreement 
with the in vitro findings of Thomas and Lochte (16).

4. A valuable opportunity to study nearly a single cohort of cells presented itself in Patient 2. This marrow, comprised almost completely of primitive megaloblasts, was exposed to $\mathrm{Fe}^{59}$ and glycine $2-\mathrm{C}^{14} 1$ hour after the patient received a large dose of vitamin $B_{12}$. The resulting heme and globin specific activities in the peripheral blood were predictable. Nearly a single cohort of cells appeared, bearing heme glycine and globin glycine millimolar specific activities that were interrelated in a manner similar to that observed on the fifth day in normal individuals. The cohort appeared between days 4 and 5. After the fifth day there was an abrupt cessation of isotope release from the marrow. These results indicate that vitamin $B_{12}$ may rapidly restore the maturation time to normal. Furthermore, if one may conclude that the primitive cells were rapidly transformed into pronormoblasts by the vitamin $B_{12}$, further evidence for a minimal maturation time of 5 days for the pronormoblasts is provided. The low "heme: globin ratio" of this cohort of cells supports the previous data regarding the higher rate of globin synthesis in the primitive normoblastic cell.

The use of radioisotopes to gain information regarding maturation and synthetic capability of hemic cells is not without pitfalls. These problems have been reviewed in our previous communication (1), but certain aspects of the megaloblastic anemias which could obscure the data must be emphasized.

1. The red cell life span is usually decreased, owing to random destruction of red cells in megaloblastic anemias (17). Subjects 1 and 4 demonstrated this abnormality as measured with $\mathrm{Cr}^{51}$-labeled autologous red cells. The $\mathrm{Cr}^{51}$ halftime was 19 days in Subject 1 and 24 days in Subject 4. Random red cell loss complicates evaluation of daily incremental specific activity, since the increment is a function not only of release of cells from the marrow but also of their removal. Variable rates of removal might seriously affect such data. In the two cases studied, the rates of red cell destruction appeared to be constant as measured with $\mathrm{Cr}^{51}$.

2. Ineffective erythropoiesis due to erythroid cell death and phagocytosis within the marrow is a characteristic of pernicious anemia. Marrow cytology, reticulocyte counts, labeled iron turnover $(3,9)$, and fecal pigment studies (18) all attest to the point that more hemoglobin and red cell synthesis occurs in the marrow of these patients than can be accounted for in the peripheral blood. Erythroid cell death and resultant intramedullary "spillage" of labeled heme and globin for "reutilization" by other erythroid cells might obfuscate the findings presented in this report. For example, one might argue that the second small peak of heme and globin glycine specific activity observed in Subjects 3 and 4 was due not to the delayed emergence of a small cohort of cells primarily exposed to the initial "pulse" of glycine$2-\mathrm{C}^{14}$, but rather that death of large numbers of erythroid cells caused sufficient release of radioactive precursors to label a population of cells that was not even present in the marrow at the time of isotope administration. To accept this argument one must first of all explain the data of Subject 1 in whom nearly all of the cells emerged after a prolonged period. If the megaloblastic cells had a normal maturation period, the bulk of the radioactivity should emerge within 4 days, and the cohort observed at 8 days should be secondary to this, as seen in Subjects 3 and 4. One must also argue that labeled cells that die in the marrow must inject free labeled glycine into the marrow in sufficient quantity to relabel protoporphyrin in newly forming cells. The globin moiety might be labeled by peptide fragments, but the protoporphyrin cannot be relabeled by catabolic products of heme degradation. Since injection into marrow might be comparable with intravenous injection, it was of interest to compare the specific activity of the urinary hippuric acid of the patients with that of normal subjects. If a sustained or sudden release of labeled glycine sufficient to relabel the protoporphyrin of a finite group of erythroid cells were to occur, one might find an increase in urinary hippuric acid specific activity at that time. The hippuric acid specific activity curves of these patients did not differ from normal. The data of Brown and Brown (19) suggest that approximately 3 per cent of the radioactivity of glycine-labeled globin may be reutilized for newly formed globin synthesis upon intravenous injection of the labeled globin in the dog. Planimetric integration of the two globin peaks of Subjects 3 and 4 demonstrated that the smaller peaks 
occupied 19 and 24 per cent of the total area under both curves. (It should be stated, however, that the exact borders of these peaks are quite arbitrarily defined.) In any case, the total radioactivity observed in the second globin peaks is greater than one would expect from reutilization of parts of labeled globin. It is of interest that a detectable, although in some cases rather small, hiatus between the emergence of cells bearing $\mathrm{Fe}^{59}$ and $\mathrm{C}^{14}$ labels in their heme is found in megaloblastic and not in normal subjects. Again one might argue that this finding represents erythroid cell death and reutilization of the $\mathrm{C}^{14}$-labeled glycine, whereas the $\mathrm{Fe}^{59}$ may have been diluted in the large stores of iron present in the megaloblastic marrows. No attempt was made to evaluate this aspect other than to note that marked delay of the emergence of a cohort of iron-labeled cells can occur, as in Subject 1.

It should be emphasized that these data in no way minimize the importance of erythroid cell death during megaloblastic maturation. Intramedullary hemolysis undoubtedly plays a major role in the development of the anemia of megaloblastosis. These studies do, however, provide evidence that prolongation of the megaloblastic maturation time is one aspect of the dyspoiesis which sufficient vitamin $B_{12}$ rapidly repairs.

\section{SUMMARY}

1. Heme and globin synthesis, together with assessment of the erythroid maturation time, has been measured after administration of glycine$2-\mathrm{C}^{14}$ and $\mathrm{Fe}^{59}$ to three patients with megaloblastic erythropoiesis due to pernicious anemia.

2. One patient with megaloblostic erythropoiesis due to pernicious anemia was treated with vitamin $\mathrm{B}_{12}$ at the time of isotope administration.

3 . The data indicate that the maturation time of the primitive megabloblast is prolonged. The prolongation may be more marked at an early stage of maturation and become more nearly normal as the cell matures.

4. Heme and globin synthesis appear to be synchronous during maturation of the megaloblastic cell.

5. Vitamin $B_{12}$ appears to shorten the maturation time and may enhance globin synthesis in the primitive cell.

\section{ACKNOWLEDGMENTS}

The authors wish to thank the Medical Service of the West Roxbury Veterans Administration Hospital for arranging the investigation of Patient 1 , and Dr. Rudi Schmid for his helpful advice throughout these studies. We are also grateful to Dr. E. Donnall Thomas for his valuable suggestions.

\section{ADDENDUM}

Attention is called to Figure 2 on p. 942 of our previous publication (1). The curves designating the ratio of cpm per mmole hemin glycine to cpm per mmole globin glycine are incorrectly plotted for Subjects 3 and 4 . The correct values for these ratios are given below.

\begin{tabular}{lccccccc} 
& \multicolumn{7}{c}{ Day } \\
\cline { 2 - 8 } & 1 & 2 & 3 & 4 & 5 & 6 & 7 \\
Subject 3 & 0.17 & 0.33 & 0.50 & 0.57 & 0.56 & 0.53 & 0.54 \\
Subject 4 & 0.20 & 0.30 & 0.49 & 0.50 & 0.49 & 0.52 & 0.51
\end{tabular}

\section{REFERENCES}

1. Nathan, D. G., Piomelli, S., and Gardner, F. H. The synthesis of heme and globin in the maturing human erythroid cell. J. clin. Invest. 1961, 40, 940.

2. Berlin, N. I., Hewitt, C., and Lotz, C. Hippuric acid synthesis in man after the administration of $\left[\alpha-{ }^{14} \mathrm{C}\right]$ glycine. Biochem. J. 1954, 58, 498.

3. Pollycove, M., and Mortimer, R. The quantitative determination of iron kinetics and hemoglobin synthesis in human subjects. J. clin. Invest. 1961, 40, 753.

4. Allen, D. W., and Jandl, J. H. Kinetics of intracellular iron in rabbit reticulocytes. Blood 1960, $15,71$.

5. Davidson, C. S., Murphy, J. C., Watson, R. J., and Castle, W. B. Comparison of the effects of massive blood transfusions and of liver extract in pernicious anemia. J. clin. Invest. 1946, 25, 858.

6. Mason, J. D., Jr., and Leavell, B. S. The effect of transfusions of erythrocytes on untreated pernicious anemia. Blood 1956, 11, 632.

7. Reisner, E. H., Jr. The nature and significance of megaloblastic blood formation. Blood 1958, 13, 313.

8. Astaldi, G. Differentiation, proliferation and maturation of haemopoietic cells studied in tissue culture in Cell Production and its Regulation, G. E. W. Wolstenholme and M. O'Connor, Eds. London, Churchill, 1960, p. 99.

9. Finch, C. A., Coleman, D. H., Motulsky, A. G., Donohue, D. M., and Reiff, R. H. Erythrokinetics in pernicious anemia. Blood 1956, 11, 807.

10. Wallerstein, R. O., and Pollycove, M. Bone marrow hemosiderin and ferrokinetics patterns in anemia. I. Pernicious anemia. A.M.A. Arch. intern. Med. 1958, 101, 418. 
11. Lajtha, L. G., and Suit, H. D. Uptake of radioactive iron $\left({ }^{50} \mathrm{Fe}\right)$ by nucleated red cells in vitro. Brit. J. Haemat. 1955, 1, 55.

12. Lajtha, L. G., and Oliver, R. Studies on the kinetics of erythropoiesis: A model of the erythron in Cell Production and its Regulation, G. E. W. Wolstenholme and M. O'Connor, Eds. London, Churchill, 1960, p. 289.

13. Wagle, S. R., Mehta, R., and Johnson, B. C. Vita$\min B_{12}$ and protein biosynthesis. VI. Relation of vitamin $B_{12}$ to amino acid activation. J. biol. Chem. 1958, 233, 619.

14. Fraser, M. J., and Holdsworth, E. S. Vitamin $B_{12}$ and protein biosynthesis in chick liver. Nature (Lond.) 1959, 183, 519.

15. Arnstein, H. R. V., and Simkin, J. L. Vitamin $B_{12}$ and biosynthesis in rat liver. Nature (Lond.) 1959, 183, 523.
16. Thomas, E. D., and Lochte, H. L., Jr. Studies on the biochemical defect of pernicious anemia. I. In vitro observations on oxygen consumption, heme synthesis and deoxyribonucleic acid synthesis by pernicious anemia bone marrow. J. clin. Invest. 1958, 37, 166.

17. Hamilton, H. E., Sheets, R. F., and DeGowin, E. L. Studies with inagglutinable erythrocyte counts. VII. Further investigation of the hemolytic mechanism in untreated pernicious anemia and the demonstration of a hemolytic property in the plasma. J. Lab. clin. Med. 1958, 51, 942.

18. London, I. M., Shemin, D., West, R., and Rittenberg, D. Heme synthesis and red blood cell dynamics in normal humans and in subjects with polycythemia vera, sickle cell anemia, and pernicious anemia. J. biol. Chem. 1949, 179, 463.

19. Brown, H., and Brown, J. Utilization of peptides in hemoglobin formation. Metabolism 1959, 8, 286. 